\title{
NEMEROFF v. ABELSON, BAD FAITH, AND AWARDS OF ATTORNEYS' FEES
}

With the recent dramatic expansion of the caseload of the federal district courts, ${ }^{1}$ judges now more than ever must take firm action to deter the litigation of unfounded claims and defenses, which is sapping both public and private legal resources. A timehonored tool for this task is the "bad faith" exception to the American Rule that each party pays its own attorneys' fees. ${ }^{2}$ This exception allows a judge to assign a reasonable amount of the prevailing party's fees to the losing party when he finds that the loser has initiated or conducted the litigation in bad faith. ${ }^{3}$

1 Overall, the number of cases pending at the end of the year rose from 93,207 in 1970 to 166,462 in 1978; the pending load per judgeship rose from 232 to 417 cases during that period. [1978] Ad. OFF. United States Courts Dir. Ann. Rep. 104-05. The last few years have seen a spate of articles in mass-circulation magazines and newspapers concerning the growing volume of litigation in this country and its potentially harmful effects on society. See, e.g., Footlick, Too Much Law?, NewsweEK, Jan. 10, 1977, at 42; Pike, Why Everybody is Suing Everybody, U.S. News \& WordD Rep., Dec. 4, 1978, at 50; Those \#"xl!l Lawyers, TIME, Apr. 10, 1978 , at 56.

2 The American Rule was first articulated in 1796 in Arcambel v. Wiseman, 3 U.S. ( 3 Dall.) 306 (1798), and has been unequivocally supported by the Supreme Court ever since. See, e.g., Alyeska Pipeline Serv. Co. v. Wilderness Soc'y, 421 U.S. 240 (1975); Fleischmann Distilling Corp. v. Maier Brewing Co., 386 U.S. 714 (1967); Hauenstein v. Lynham, 100 U.S. 483 (1880); Stewart v. Sonneborn, 98 U.S. 187 (1879); Oelrichs v. Spain, 82 U.S. (15 Wall.) 211 (1872). In Alyeska, the most significant recent case on the subject, the Court discussed the history of the rule at some length. The rule is generally supported on two grounds: that it would be unfair to penalize an honest litigant merely for bringing a claim or offering a defense; and that to hold a party liable for the victor's legal fees would unjustly deter the poor from vindicating their rights in the courts, Fleischmann Distilling Corp., 386 U.S. at 718.

In contrast to the American Rule, the general rule in Great Britain and most other western countries is that the losing party pays the attorneys' fees of the prevailing party. McCormick, Counsel Fees and Other Expenses of Litigation as an Element of Damages, 15 Min. L. REv. 619, 619-21 (1931); Stoebuck, Counsel Fees Included in Costs: A Logical Development, 38 U. Colo. L. REv. 202, 204-07 (1966). For a brief discussion of the British rule by the United States Supreme Court, see Fleischmann Distilling Corp., 386 U.S. at 717 (1966).

3 Such "fee shifting" under the bad faith exception is limited to those expenses that the prevailing party has reasonably incurred to meet the bad faith claims or defenses of his opponent. Browning Debenture Holders' Comm. v. DASA Corp., 560 F.2d 1078, 1089 (2d Cir. 1977). For discussions of what fees are "reasonable," see Berger, Court Awarded Attorneys' Fees: What is "Reasonable"?, 126 U. PA. L. REv. 281 (1977); Comment, Court Awarded Attorney's Fees and Equal Access to the Courts, 122 U. PA. L. Rev. 636, 701-13 (1974).

In reaffirming the American Rule, the Alyeska Court also reiterated its support of the bad faith exception: "a court may assess attorneys" fees . . . when the losing party has 'acted in bad faith, vexatiously, wantonly, or for oppressive reasons .... These exceptions are unquestionably assertions of inherent power in the courts to allow attorneys' fees in particular situations, unless forbidden by Congress ...." Alyeska Pipeline Serv. Co. v. Wilderness Soc'y, 421 U.S. 240, 258-59 
The recent case of Nemeroff $v$. Abelson ${ }^{4}$ appears to represent one attempt to put more "bite" into the bad faith exception for deterrent purposes. Judge Carter's decision, however, points up the need to consider squarely what procedural requirements and safeguards of fairness are or should be triggered by invocation of the exception. Courts have devoted little overt attention to these matters, and commentators have tended to concentrate on attacking the American Rule as a whole ${ }^{5}$ rather than on making suggestions for its improvement.

This Comment first analyzes the Nemeroff opinion and related case law in order to explore the nature of the prerequisites for shifting attorneys' fees under the bad faith exception. ${ }^{8}$ Second, the Comment discusses a crucial question raised but not expressly addressed in the Nemeroff opinion: what type of proof is required to establish that a claim was brought with improper motive? ${ }^{7}$ More precisely, may a court simply infer improper motive from the evidence adduced to support the claim or from the party's conduct during the litigation, or must an evidentiary hearing into motive be conducted if desired by either party? The Comment concludes that a party should be given time to discover and present evidence directly bearing on the state of mind of the litigant against whom fees are sought. Although such an opportunity should always be provided before an award of attorneys' fees is granted or denied, procedures are recommended that will obviate the need for a full-

(1975) (citations omitted). For earlier decisions confirming the exception, see F.D. Rich Co. v. Indus. Lumber Co., 417 U.S. 116, 129 (1974); Hall v. Cole, 412 U.S. 1, 5 (1973); Newman v. Piggie Park Enterprises, 390 U.S. 400, 402 n.4 (1968). For a general discussion of the exception, and especially its applicability to state court systems, see Comment, Attorney's Fees and the Federal Bad Faith Exception, 29 Hastings L.J. 319, 332 (1977). See also Court Awarded Attomey's Fees and Equal Access to the Courts, supra, at 689-92.

4469 F. Supp. 630 (S.D.N.Y.), appeal docketed, No. 79-7366 (2d Cir. May $25,1979)$.

5 See, e.g., Ehrzenweig, Reimbursement of Counsel Fees and the Great Society, 54 CAL. L. REv. 792 (1966); Kuenzel, The Attorney's Fees: Why Not a Cost of Litigation?, 49 Iowa L. Rev. 75 (1963); McCormick, supra note 2; Stoebuck, supra note 2; Court Awarded Attorney's Fees and Equal Access to the Courts, supra note 3, at 648-55. See also note 130 infra.

6 There are two general applications of the bad faith exception; only the first is discussed in this Comment. The first concerns bad faith in the litigation itself, including pressing a suit or defense for an improper purpose. The second comes into play when the court finds that the obdurate obstinacy of the defendant forced the plaintiff to resort to the courts to vindicate legal claims of unquestionable validity. See, e.g., Hutto v. Finney, 437 U.S. 678, 689 n.I4 (1978); Vaughan v. Atkinson, 369 U.S. 527 (1962); Huecker v. Milburn, 538 F.2d 1241 (6th Cir. 1976); Richardson v. Communications Workers of America, 530 F.2d 126 (8th Cir.), cert. denied, 429 U.S. 824 (1976).

7 The question of motive is the third and last stage of analysis in the application of the bad faith exception. See text accompanying notes 22-27 infra. 
scale trial-like hearing in every case. Finally, this Comment suggests that the inescapable procedural costs of a rule that requires subjective bad faith may provide one more argument for abandoning the American Rule altogether in favor of a regime of routine fee shifting, aimed at compensation rather than punishment, in cases involving groundless claims.

\section{Nemeroff v. Abelson}

Dr. Robert Nemeroff invested heavily in the stock of Technicare Corporation. After a spectacular rise, the stock dropped slightly in price-just around the time Alan Abelson published several articles critical of the stock in Barron's National Business and Financial Weekly. ${ }^{8}$ Nemeroff then filed suit against Abelson, the editor and the publisher of Barron's, and certain short sellers ${ }^{\circ}$ of Technicare stock, alleging that Abelson had leaked word of those forthcoming negative columns on Technicare to the sellers in violation of sections 9 (a) and 10 (b) of the Securities Exchange Act of 1934. ${ }^{10}$ Several months after the complaint was filed, it was amended to charge that the short sellers had solicited Abelson to write negative stories about Technicare. ${ }^{11}$

About ten months after the initial complaint was filed, Judge Carter granted the plaintiff's motion to dismiss the action voluntarily with prejudice. ${ }^{12}$ The dismissal was to be effective after an interim period during which the defendants had leave to and did file a motion for attorneys' fees on the basis of plaintiff's alleged bad faith in bringing the action. ${ }^{13}$ After hearing oral argument on the legal issues raised by the motion, the court found that the suit had been filed in bad faith as against the publishing defendants, but not as against the defendant short sellers, and ordered Nemeroff and his attorneys to pay a substantial portion of the publishing defendants' legal expenses. ${ }^{14}$

8 Nemeroff v. Abelson, 469 F. Supp. 630, 633 (S.D.N.Y.), appeal docketed, No. 79-7366 (2d Cir. May 25, 1979). The articles appeared in Abelson's regularly published column, "Up and Down Wall Street." Id.

9 Short sellers are those who agree to sell stock they do not yet own at a future date for a set price, in the hope that they will be able to acquire the stock before that date at a lower price. Thus, short sellers stand to make money in a falling market, but risk losing money if the market rises.

1015 U.S.C. $\$ \$ 78 i(a), 78 j(b)(1976)$.

11 Nemeroff v. Abelson, 469 F. Supp. 630, 632 (S.D.N.Y.), appeal docketed, No. 79-7366 (2d Cir. May 25, 1979).

$12 I d$.

13 Id.

${ }^{14}$ No attorneys' fees were awarded to the short sellers. The basis for this distinction between defendants was that while the potential for damage to the 
Substantial disputes arose in Nemeroff regarding the precise nature of the pre- and post-complaint investigation into the alleged wrongdoings. The court fixed most of its attention on the amount of information the plaintiff's attorneys had been able to gather to verify their claims before they filed suit. ${ }^{15}$ Judge Carter found that the plaintiff's investigation had turned up very little evidence that would be "admissible in this case," and that what admissible evidence there was would not be very helpful in substantiating his claims. ${ }^{16}$ On the other hand, it was undisputed that plaintiff's attorney had investigated the claim; this was not a case in which the attorneys merely listened to the client's allegations and immediately commenced litigation on that basis alone. An experienced attorney with the Boston law frm of Hale and Dorr interviewed potential witnesses, gathered documents bearing on the buying patterns of the short sellers in relation to the publication dates of Abelson's columns, obtained information on social relationships between the short sellers and the publishing defendants, and followed up a magazine article that had alleged a similar scheme by the publishing defendants to drive down the price of another corporation. ${ }^{17}$

It is apparent that the court based its finding of bad faith in regard to the publishing defendants largely on what it considered to be the inadmissible and irrelevant nature of the evidence that the plaintiff's attorneys possessed at the time the complaint was withdrawn. "To make and disseminate allegations such as those made here without the slightest assurance that plaintiff's burden of proof could be met, when it is known or should have been known that no hard facts but only rumor and gossip support the charges," the judge

reputations of the publishing defendants was very great-because of their roles as analysts and purveyors of information in the investment community-id. 639-40, the potential for harm to the short sellers as a result of the plaintiff's "baseless" allegations was virtually nonexistent, because the complaint would only enhance their reputations as "discerning and skillful speculators," $i d .641$.

The widespread application of the historical standard of bad faith is made clear in Judge Carter's statement that

[t]he ultimate question concerning taxing of attorneys' fees and expenses as costs against plaintiff and/or his counsel under [FED. R. Crv. P. II; $\S 9(\mathrm{e})$ of the Securities Exchange Act of 1934, 15 U.S.C. $\$ 78 \mathrm{i}(\mathrm{e})$ (1976)] or the court's equitable power is whether the plaintiff and/or counsel instituted the action "in bad faith, vexatiously, wantonly, or for oppressive reasons."

Nemeroff v. Abelson, 469 F. Supp. 630, 637 (S.D.N.Y.), appeal docketed, No. 79-7366 (2d Cir. May 25, 1979) (citations omitted).

15 For Judge Carter's detailed narrative of the investigation, see id. 633-35. 16 Id. 639.

17 Id. $633-35,637$ n.5. 
chided, "constitutes the essence of bad faith." 18 Having drawn sweeping inferences regarding plaintiff's motive from examining this evidence, Judge Carter proceeded to interpret the premature "leakage" of the complaint to a newspaper as intentional and malicious. ${ }^{19} \mathrm{He}$ did so without benefit of having heard the parties present and test evidence directly related to the issue of plaintiff's motive. ${ }^{20}$ And even so, plaintiff's counsel may not have had sufficient notice that material issues of fact concerning the institution of the suit were to be addressed and resolved through briefing and oral argument. Under such circumstances, Judge Carter's conclusions seem hastily drawn:

[P]laintiff and his counsel knowingly proceeded with litigation that lacked foundation. Clearly, the purpose could not have been to litigate on the merits. Indeed, the only rational inference to be drawn is that plaintiff's and his counsel's real objective was the public airing of the damaging allegations against the publishing defendants-an objective achieved with the filing of the complaint. ${ }^{21}$

In sum, Judge Carter did make a finding that the plaintiff had brought the suit in subjective bad faith, but his finding was based purely on "rational inferences" without an independent, procedurally fair factual determination of the plaintiff's motive.

\section{The Elements of Bad Faith Litrgation}

Analysis of the case law indicates, as the Nemeroff opinion states, ${ }^{22}$ that three elements must be present in order for a court to grant a motion to award fees under the bad faith exception. First, the movant must be the prevailing party. ${ }^{23}$ Second, the claim

18 Id. 640.

19 Id. 635.

20 See note 102 infra \& accompanying text.

21 Nemeroff v. Abelson, 469 F. Supp. 630, 636 (S.D.N.Y.), appeal docketed, No. 79-7366 (2d Cir. May 25, 1979).

22 See notes $23,24 \& 27$ infra.

23 Alyeska Pipeline Serv. Co. v. Wilderness Soc'y, 421 U.S. 240, 258-59 (1975); Nemeroff v. Abelson, 469 F. Supp. 630, 641 (S.D.N.Y.), appeal docketed, No. 79-7366 ( $2 \mathrm{~d}$ Cir. May 25, 1979). The rationale for the prevailing-party requirement is closely linked to the second element of the bad faith exception, see text accompanying note 25 infra: a claim cannot be without merit if the opponent is not able to defeat it. For a discussion of the difficulty of determining whether or not a party has prevailed, including consideration of cases in which a claim is voluntarily withdrawn, see Nemeroff v. Abelson, 469 F. Supp. at 641-42. 
or defense provoking the motion must be unfounded, ${ }^{24}$ or even "entirely without color" 25 or "wholly without foundation." 26 Third, the claim or defense must have been lodged with a bad motive, such as harassment. ${ }^{27}$ The purpose of this Comment is to explore the nature of the second and third requirements in an effort to emphasize the distinction between them and to encourage courts to avoid blurring that distinction.

\section{A. The Lack of Foundation of the Claim or Defense}

If the court decides that a claim or defense is unfoundedthe second requirement for granting a motion for fees under the bad faith exception-the focus of the inquiry shifts to the critical issue of motive, or purpose. ${ }^{28}$ However, if the court finds that the claim was not unfounded, the fee-shifting motion must be denied, and an inquiry into motive becomes irrelevant. ${ }^{29}$ Thus, except when the bona fides of conduct at trial are challenged,,$^{30}$ the bad faith exception generally is inapplicable to cases in which a trial has been conducted and a verdict rendered, because the necessity of a full trial suggests that the claim had at least some merit. The analysis and conclusions set forth in this Comment will usually be restricted, therefore, to lawsuits that are not fully tried. ${ }^{31}$

24 Kinnear-Weed Corp. v. Humble Oil \& Refining Co., 441 F.2d 631, 637 (5th Cir.), cert. denied, 404 U.S. 941 (1971); Nemeroff v. Abelson, 469 F. Supp. 630, 633 (S.D.N.Y.), appeal docketed, No. 79-7366 (2d Cir. May 25, 1979). See 6 Moore's Federal Practice \54.77[2], at 1709 (2d ed. 1979).

(2d Cir. 1977).

25 Browning Debenture Holders' Comm. v. DASA Corp., 560 F.2d 1078, 1088

${ }^{26}$ In re Slodov, [1979] Fed. Taxes (P-H) (43 A.F.T.R.2d 79-961) I 79-499, at 79-968 (N.D. Ohio).

$2 \tau$ Hall v. Cole, 412 U.S. 1, 5 (1972); Nemeroff v. Abelson, 469 F. Supp. 630, 633, 640 (S.D.N.Y.), appeal docketed, No. $79-7366$ (2d Cir. May 25, 1979); Browning Debenture Holders' Comm. v. DASA Corp., 560 F.2d 1078, 1088 (2d Cir. 1977).

28 See text accompanying notes 40-56 infra.

29 The court in Browning Debenture Holders' Comm. v. DASA Corp., 560 F.2d 1078 (2d Cir. 1977), stated that "[a]n action is brought in bad faith when the claim is entirely without color and has been asserted wantonly, for purposes of harassment or delay, or for other improper reasons." Id. 1088 (emphasis added). The conjunctive formulation implies that if either one of the conditions is not fulfilled, the motion must be denied. The importance of this point lies in the very real possibility that a colorable legal claim may be pressed for purposes other than those usually recognized as "proper."

30 See note 40 infra.

31 Occasionally, a court may exercise its discretion to award fees under the common law bad faith exception after a full trial on the plaintiff's claim. However, because the court has observed the parties' testimony and demeanor during trial and perhaps heard the defendant put the question of plaintiff's motive into issue, a post-trial finding of malice is not usually subject to the same procedural deficiencies that a pre-trial finding of bad faith is. See, e.g., Copeland v. Martinez, $435 \mathrm{~F}$. Supp. 1178 (D.D.C. 1977), affd, 603 F.2d 981 (D.C. Cir. 1979). 
Acknowledging the foregoing scheme, Judge Carter found the litigation in Nemeroff unfounded "because plaintiff's attorney knew or should have known that the gossip which he recited in his affidavit is not evidentiary proof." 32 The plaintiff's motive in instituting suit was therefore put in issue. But was there any basis for reaching the motive issue so quickly simply because the evidence offered by plaintiff in support of his claim would be mostly inadmissible and immaterial at trial? As will be seen, the answer seems to be that Judge Carter's action was not inappropriate.

The case law contains little discussion of when a claim is or is not unfounded for purposes of applying the bad faith exception. When courts dispose of suits summarily, they often rest their findings of lack of foundation simply on that summary disposition..$^{33}$ Because the motion for fees in Nemeroff followed a voluntary dismissal ${ }^{34}$ without a decision on the merits, the court had to address explicitly the basis of the complaint. Judge Carter ruled that the claim was unfounded ${ }^{35}$ due to the "insubstantial" ${ }^{36}$ and inadmissible ${ }^{37}$ character of the plaintiff's evidence. Inasmuch as courts commonly proceed to the issue of motive as soon as a claim or defense has been disposed of by directed verdict or other summary

32 Nemeroff v. Abelson, 469 F. Supp. 630, 639 (S.D.N.Y.), appeal docketed, No. 79-7366 (2d Cir. May 25, 1979).

33 See, e.g., Gage v. Wexler, 82 F.R.D. 717 (N.D. Cal. 1979); Aid Auto Stores, Inc. v. Cannon, 525 F.2d 468 (2d Cir. 1975); Katz v. Delka Research Corp. of N.J., 295 F. Supp. 647 (S.D.N.Y. 1968), aff'd sub nom. Katz v. Amos Treat \& Co., 411 F.2d 1046 (2d Cir. 1969). In Gage, "[t]he groundlessness of plaintiff's suit is best demonstrated in the facts set forth in the Memorandum of Opinion dismissing his complaint for failure to state a claim." 82 F.R.D. at 718. Gage was a suit brought under 42 U.S.C. $\$ 2000 \mathrm{e}-5(\mathrm{k})$ (1976); according to the standard articulated in Christianburg Garment Co. v. EEOC, 434 U.S. 412 (1978), no finding of bad faith was required. See text accompanying notes 48-50 infra.

34 Below, this Comment proposes that, for reasons of judicial economy, a voluntary dismissal should almost always automatically preclude a motion for attorneys fees. See text accompanying notes 112-16 infra. In the absence of such a rule, the analysis offered here would apply.

35 Judge Carter described Nemeroff's claim as "baseless" because Nemeroff did not have "one iota of proof-in the sense that term is defined in a court of law." Nemeroff v. Abelson, 469 F. Supp. 630, 635 (S.D.N.Y.), appeal docketed, No. 79-7366 ( $2 \mathrm{~d}$ Cir. May 25, 1979). This choice of terms was unfortunate to the extent that "baseless" implies that the plaintiff had not even a sincere suspicion of wrongdoing when he brought the suit. As will be discussed below, lack of factual foundation is not tantamount to insincerity. See text accompanying notes 39 \& 66-68 infra. Indeed, the fatal Hlaw of the Nemeroff opinion is Judge Carter's blurring of the evidentiary standard used in determining whether a claim is unfounded with the state-of-mind standard which must be used to decide the crucial question of bad faith. See text accompanying notes 40-56 infra.

36 Nemeroff v. Abelson, 469 F. Supp. 630, 637 (S.D.N.Y.), appeal docketed, No. 79-7366 (2d Cir. May 25, 1979).

37 Id. 639. 
procedure, it was not inappropriate, in principle, for Judge Carter to have reviewed Nemeroff's evidence using standards similar to those used for summary judgment on the merits and to have deemed the claim unfounded for purposes of applying the bad faith exception: ${ }^{38}$ a party should not be able to block further consideration of a fee-shifting motion when his claim was grounded in circumstances, hearsay, gossip, and other inadmissible or inconclusive evidence. Such evidence, however, may be probative of a party's reasonable suspicions of wrongdoing, and as such, although not sufficient to provide legal foundation for the claim, ${ }^{39}$ relevant to a determination of motive.

\section{B. The Bad Faith Motive}

Once a court has determined that a claim is unfounded, another, more crucial, finding of fact is required if fees are to be shifted. It is not enough that a party has brought a claim that is totally without color: well-settled doctrine provides that the claim must also have been "asserted wantonly, for purposes of harassment or delay, or for other improper reasons." 40 Justice Brennan, in the Supreme Court's reaffirmation of the bad faith exception in Hall $v$. Cole, ${ }^{41}$ observed that "[i] $\mathrm{n}$ this class of cases, the underlying rationale of 'fee shifting' is, of course, punitive, and the essential element in triggering the award of fees is therefore the existence of 'bad faith' on the part of the unsuccessful litigant." 42

38 Motions for summary judgment must be decided on the basis of the admissible evidence contained in the affidavits and other written submissions. FED. $R$. Crv. P. 56(e). See, e.g., Munoz v. Int'l Alliance of Theater Stage Employees, 563 F.2d 205 (5th Cir. 1977); Hamilton v. Keystone Tankship Corp., 539 F.2d 684 (9th Cir. 1976); Daily Press, Inc. v. United Press Int'l, 412 F.2d 126 (6th Cir.), cert. denied, 396 U.S. 990 (1969).

39 See cases cited in note 33 supra.

40 Browning Debenture Holders' Comm. v. DASA Corp., 560 F.2d 1078 (2d Cir. 1977). In Browning, a Second Circuit panel limited the district court's award of fees to "expenses reasonably incurred to meet the other party's groundless, bad faith procedural moves." Expenses for the entire defense were not allowed because the action itself was not found to have been brought in bad faith. Id. 1089 . Procedures found to have been used in bad faith included the appeal of mooted issues, delay for discovery never undertaken, service of dragnet subpoenas, and threats to depose numerous officials of the defendant corporation. Id. 1088-89.

Although the need for a separate inquiry into motive is sometimes not as pronounced in procedural bad faith cases as in cases involving allegedly bad faith claims or defenses-because the court will have had an opportunity to observe the behavior of the party opposing the motion-the standards for awarding fees are the same, as Browning illustrates, and the same considerations of fairness to the parties must be addressed. See notes 59-62 infra \& accompanying text.

$\$ 1412$ U.S. 1 (1973).

42 Id. 5. 
Taken at face value, the Nemeroff opinion fully recognizes the need to find actual malice, rather than merely lack of foundation, in order to award fees. ${ }^{43}$ However, as noted earlier, ${ }^{44}$ the court based its finding of bad faith almost exclusively on an evidentiary standard: it inferred bad faith largely from the inadequacy of the plaintiff's case, without focusing on independent, direct evidence of actual malice. Although some such evidence was adduced in the form of two affidavits suggesting that the original complaint had been "leaked" to the press, the court devoted a mere paragraph to this episode and accepted the truth of these critical affidavits without testing their credibility or attempting to determine whether the alleged leak had been intentional. ${ }^{45}$ Nemeroff is not unique for its glib treatment of the motive issue, ${ }^{46}$ but, as will be demonstrated below, such treatment is unfair to the parties. Procedures for determining bad faith that deemphasize or completely omit direct evidence of actual malice or willful disregard for the truth undermine the subjective bad faith requirement. At the very least, Nemeroff-type analyses create confusion in the law detrimental to the proper disposition of fee-shifting motions under the exception.

For purposes of the bad faith exception, a litigant's behavior is not measured by an objective "reasonable man" standard, as some courts seem to imply. ${ }^{47}$ Rather, a court must make a subjective determination of the litigant's state of mind at the time he pressed his claim. The Supreme Court recently clarified this distinction in Christianburg Garment Co. v. EEOC, ${ }^{48}$ involving a defendant's claim for fees under section $706(\mathrm{k})$ of Title VII of the 1964 Civil Rights Act, ${ }^{49}$ which gives a court discretion to award attorneys' fees to the prevailing party. Arguing that such discretion was to be exercised solely in favor of plaintiffs who had served as "private attorneys general," the plaintiff in Christianburg maintained that

43 Nemeroff v. Abelson, 469 F. Supp. 630, 640 (S.D.N.Y.), appeal docketed, No. 79-7366 (2d Cir. May 25, 1979).

44 See text following note 17 supra.

45 Nemeroff v. Abelson, 469 F. Supp. 630, 635 (S.D.N.Y.), appeal docketed, No. 79-7366 (2d Cir. May 25, 1979). See notes 102-05 infra \& accompanying text. 46 See notes 57-62 \& 68-71 infra \& accompanying text.

${ }_{47}$ E.g., Aid Auto Stores, Inc. v. Cannon, 525 F.2d 468, 471-72 (2d Cir. 1975) ("In short, although the evidence adduced at trial was plainly insufficient . . . there were grounds for suspecting [defendant's] complicity, which entitled [plaintiff] Aid to institute the action with a view to discovering sufficient proof to enable it to prove its charges at the time of trial."); Katz v. Delka Research Corp. of N.J., 295 F. Supp. 647 (S.D.N.Y. 1968), aff'd sub nom. Katz v. Amos Treat \& Co., 411 F.2d 1046 (2d Cir. 1969).

48434 U.S. 412 (1978).

4942 U.S.C. $\$ 2000 \mathrm{e}-5(\mathrm{k})$ (1976). 
the traditional bad faith standard should be applied when the defendant moved for a fee award. The Supreme Court rejected this argument, reasoning that Congress would not have written an attorneys' fees clause into the statute if it had meant the courts to continue applying the common law standard. ${ }^{50}$ The Court thus determined that use of the less restrictive objective test was appropriate for awarding fees under the statute and, by implication, inappropriate under the traditional bad faith exception: "In sum, a district court may in its discretion award attorneys' fees to a prevailing defendant in a Title VII case upon a finding that the plaintiff's action was frivolous, unreasonable, or without foundation, even though not brought in subjective bad faith." 51

This "additional" subjective element of the common law bad faith exception means that an "unreasonable man" can bring a suit and not be taxed fees. Because state of mind is critical, the central question in fee-shifting motions under the exception should not be whether a party's suspicions were reasonable, but whether he had sincere suspicions that he intended to substantiate by means of the discovery process for the purpose of adjudicating a grievance or asserting an affirmative defense. By inferring bad faith largely from the plaintiff's lack of admissible evidence, ${ }^{52}$ Judge Carter confused this distinction ${ }^{53}$ in Nemeroff. His analysis may lead the casual reader to think that because plaintiff's attorneys "should have known that no hard facts but only rumor and gossip" 54 supported the charges, sufficient grounds existed to award fees. But the test for awarding fees is whether the plaintiff and his attorney

50434 U.S. 412,419 (1978).

51 Id. 421 (emphasis added). The Court's implied conclusion about the bad faith exception is dictum, but the passage is not used here to show that a bad motive is a prerequisite to common law fee shifting-Hall v. Cole, 412 U.S. I (1973), established that. Rather, the passage is offered to illustrate the contrast between the two modes of fee shifting.

62 See text following note 17 supra.

53 The opinion states at the beginning of its determination of facts that "[t]his lawsuit was instituted based on very strong convictions of wrongdoing, but it was a conviction colored by greed." Nemeroff v. Abelson, 469 F. Supp. 630, 635 (S.D.N.Y.), appeal docketed, No. 79-7366 (2d Cir. May 25, 1979). Judge Carter apparently believed that Nemeroff's suspicions had been sincere, but that he had been unable to realize the unreasonableness of his lawsuit because greed had distorted his perceptions. An award of fees on this rationale is subject to criticism. It is hard to imagine a person who could retain an air of complete objectivity about what he considers a major grievance. Nemeroff could indeed have been angered to the point where his suspicions might strike the detached observer as unreasonable. If circumstances show that a particular plaintiff sincerely believed wrongdoing had occurred and could be uncovered by discovery, then fee shifting is inappropriate under the traditional bad faith exception.

54 Id. 640 . 
actually did know their claim was unsupportable-not whether they should have known it. At most, the objective unreasonableness of a claim yields an inference or perhaps a prima facie case of bad faith; ${ }^{55}$ but the party pressing the claim should have an opportunity to rebut and, if necessary, fully litigate the question of actual malice..$^{56}$

\section{Proof of Motive}

\section{A. Differing Views}

Judge Carter is not the only judge to make a finding on motive without seeking any direct, testimonial evidence on the actual state of mind of the party opposing the attorneys' fees motion. In Kinnear-Weed Corp. v. Humble Oil of Refining Co., ${ }^{57}$ for example, the plaintiff charged Humble with altering an evidentiary exhibit, but after extensive discovery plaintiff's counsel conceded that there was no basis for the accusation. A Fifth Circuit panel upheld the award of fees to Humble under the bad faith exception even though the award had not been based on any direct evidence of improper motive. ${ }^{58}$

Similarly, several courts have awarded fees after inferring bad faith from the dilatory or evasive actions of a party during trial without having heard evidence bearing specifically on motive. ${ }^{59}$ The need for such a separate inquiry varies in these cases, depending upon the nature of the abuse and the opportunity for the court to observe the behavior of the alleged abuser, but the standards for

55 Inferences, unlike presumptions, are based on logic, not rules of law. It is not illogical to infer that, if a party presses a claim on the basis of an investigation that turned up no admissible supporting evidence, he may well be doing so for a purpose other than the just adjudication of his grievance. See McCormack's HANDBOOK OF THE LAW OF EvMEENCE $\$ 342$, at 803-04 (2d ed. E. Cleary 1972); R. Freld, B. Kaplan, \& K. Clemmont, Civm Procedure 497 (4th ed. 1978). The effect of such an inference is to satisfy the movant's burden of production, that is, to guarantee that the motion will be considered by the factfinder rather than be dismissed out of hand for lack of support. The inferences that may be drawn from the objective evidence will at times be so strong that the burden of production will actually shift to the opposing party. In such cases, the opposing party will lose the motion if he does not come forward with evidence to refute the inference.

56 See text following note 121 infra.

57441 F.2d 631 (5th Cir.), cert. denied, 404 U.S. 941 (1971).

58 Id. 636-37.

59 Examples other than those discussed in the text are Huecker v. Milburn, 538 F.2d 1241, 1246 \& n.11 (6th Cir. 1976); First Nat'l Bank in Sioux Falls v. Dunham, 471 F.2d 712 (8th Cir. 1973). In Dunham, although the bad faith exception was not referred to by name, defendant's actions were so extremely offensive that the court awarded fees for "dominating reasons of justice" relating to the defendant's bad faith conduct. Id. 713 . 
applying the bad faith exception are the same as in the claim-ordefense cases and the concern with fairness to the parties is no less appropriate. ${ }^{60}$ Improper motive has been inferred in the procedural-abuse cases when, for example, after being informed by the defendants and warned by the judge that all of the federal claims in the complaint were facially deficient and barred by the statutes of limitation, the plaintiff insisted on continuing the litigation. ${ }^{61}$ When, in another case, defendants continually denied facts well known to all, forcing plaintiffs to spend a great deal of time and money unnecessarily, the court shifted fees, citing the "purposeful stratagem of delay for delay's sake." ${ }^{22}$

The use of inferences as a basis for a fee award disadvantages the party opposing the award who might desire and benefit from the opportunity to present rebuttal evidence demonstrating his good faith. Set against the weight of the cases that have foreclosed this opportunity, however, are a pair of appellate opinions that deal with taxing attorneys with costs on the basis of similar considerations: These cases suggest in dictum that an evidentiary hearing in court might have to be conducted on the issue of motive. The court in Hanley $v$. Condrey, ${ }^{63}$ for instance, sidestepped the question whether to assess costs against an attorney because it felt the amount of litigation in the case was already excessive, but it noted along the way that a decision to so assess costs might "require notice and a hearing." " ${ }^{4}$ The court's conclusion was based on a Fifth Circuit panel's decision in Miles $v$. Dickson ${ }^{65}$ in which it was posited, also in dictum, that to assess costs against attorneys without notice and a hearing would be wrong. In light of attorneys' greater knowledge of the law and the legal consequences of their actions, their clients should be entitled to at least the same procedural safeguards in fee-shifting motions.

60 See note 40 supra \& references therein.

61 Gage v. Wexler, 82 F.R.D. 717 (N.D. Cal. 1979).

62 Gates v. Collier, 70 F.R.D. 341, 345 (N.D. Miss. 1976), affd in part, reo'd in part, 559 F.2d 241 (5th Cir. 1977). In Gates, the district court awarded fees incurred during trial only. The Fifth Circuit panel affirmed the award of trial fees and reversed the lower court's refusal to award fees incurred in earlier appellate proceedings. 559 F.2d 241.

63467 F.2d 697 (2d Cir. 1972).

61 Id. 700. The basis of the assessment of costs in Hanley was 28 U.S.C. $\$ 1927$ (1976), which provides for awards against a person "who so multiplies the proceedings in any case as to increase costs unreasonably and vexatiously."

65387 F.2d 716 (5th Cir. 1967). The reason no costs were assessed in Miles was that the attorneys had acted in "good faith." Id. 717. See generally Satoskar v. Indiana Real Estate Comm'n, 517 F.2d 696 (7th Cir.) (question of appeals taken in bad faith), cest. denied, 423 U.S. 928 (1975); Walker v. Columbia Broadcast. Sys., Inc., 443 F.2d 33, 38 (7th Cir. 1971). 
The party being taxed with fees is not the only party who might desire the opportunity to present or discover evidence specifically relating to his subjective state of mind. It can happen that a court will use an objective standard to infer that a claim was based on reasonable suspicions and thus brought in good faith, ${ }^{66}$ whereas the defendant ${ }^{67}$ believes motive-related depositions or courtroom cross-examination would reveal subjective bad faith. Those courts that hold that bad faith cannot be inferred from a lack of factual foundation when the plaintiff has heard or seen anything that could reasonably lead him to suspect wrongdoing place the movant for attorneys' fees in a difficult position-he must present additional, direct evidence on motive if he is to prevail. Yet these opinions do not address the basic problem that they raise: Should a party requesting attorneys' fees under the bad faith exception always be allowed, when he makes his desire known to the court, to present independent evidence specifically addressed to the motive issue?

At least one court has explicitly declined to order a hearing under such circumstances. In Larchmont Engineering, Inc. v. Toggenburg Ski Center, Inc., ${ }^{68}$ a Second Circuit panel inferred good faith from the plaintiff's voluntary dismissal with prejudice and affirmed the district court's denial of the defendants' specific request to present evidence showing the plaintiff's bad faith. The decision could be read narrowly as motivated by the court's overriding desire to encourage voluntary dismissals by granting such plaintiffs a form of immunity ${ }^{69}$-a policy which this Comment approves. ${ }^{30}$ However, the court's lack of enthusiasm for a motiverelated hearing in Larchmont may have reflected its attitude toward all motions for attorneys' fees under the bad faith exception. The judges spoke in broad terms of the need to rely on the trial court's discretion in order that it "should not be straitjacketed by a ruling that would have the effect of mandating a hearing." 71 The

66 See note 47 supra.

67 In the interest of simplicity, and except in the context of particular decided cases, "defendant" will be used to identify the party against whom a claim or defense is raised; "plaintiff" will identify the party pressing the claim-the party whose motive is at issue.

68444 F.2d 490 (2d Cir. 1971).

69 Id. 491: "After pretrial discovery revealed the weaknesses of its claims, Larchmont may well have decided in good faith to minimize litigation expense by foregoing its claims and by taking a voluntary dismissal. Such a move should not be discouraged by the threat of imposing attorneys fees." See note 112 infra.

70 See text accompanying notes 112-16 infra.

71 Larchmont Eng'r, Inc. v. Toggenburg Ski Center, 444 F.2d 490, 491 (2d Cir. 1971). 
opinion left unclear, though, what, if anything, a trial judge should consider in exercising his discretion.

At least one district court has attempted to establish an intermediate procedure for determining whether a prima facie case for award of fees has been established, thus necessitating further discovery and possibly an adversary hearing. ${ }^{72}$ Its solution was to allow a "less costly presentation of written evidence"-a "quasisummary judgment" motion ${ }^{73}$-in which an "extremely heavy burden of proof" 74 would be imposed on the movant.

The dominant impression left by a survey of cases involving. the bad faith exception is that courts have been extremely reluctant to set in motion litigation over the issue of subjective intent, even though the American Rule with regard to attorneys' fees would seem to require it, in the absence of a modifying statute. ${ }^{75}$ Analogy to the long-established tort for malicious prosecution lends further support to the view that parties in a fee-shifting dispute should be granted an opportunity to present independent evidence of subjective intent. At the same time, well-settled rules of summary judgment offer a yardstick by which judges could fairly treat motions for "bad faith" attorneys' fees without necessitating a fullblown trial in every case. This section therefore concludes with a consideration of malicious prosecution and summary judgment and their implications for fee-shifting under the "bad faith" exception.

\section{B. A Comparison with Malicious Prosecution}

The similarity between the bad faith exception to the American Rule and the tort of malicious prosecution ${ }^{76}$ is readily apparent: liability for the tort is established only when the "prosecution" on which the claim is based has terminated in favor of the defendant; ${ }^{77}$ the alleged tortfeasor has been found to have brought the suit without probable cause; ${ }^{78}$ and the purpose of the suit has been found

72 W.L. Gore \& Assoc., Inc. v. Oak Materials Group, Inc., 424 F. Supp. 700

(D. Del. 1976).

73 Id. 702.

74 Id. 703.

${ }^{75}$ See notes 50 \& 51 supra \& accompanying text.

76 On the subject of malicious prosecution, see generally Note, Groundless Litigation and the Malicious Prosecution Debate: A Historical Analysis, 88 YauE L.J. 1218 (1979); Restatement (SECOND) of ToRts \$674 (1977). party").

$77 \mathrm{Cf}$. text accompanying note 23 supra (movant for fees must be "prevailing

$78 \mathrm{Cf}$. text accompanying notes 24-26 supra (opposing party's claim must have been unfounded). Probable cause in malicious prosecution is a lenient concept: the plaintiff need only reasonably believe in the existence of facts upon which to 
to have been other than to properly adjudicate a colorable claim. ${ }^{79}$ It should not be surprising, therefore, that several courts have suggested that the standards for application of the bad faith exception are similar to those for fixing liability for the tort. ${ }^{80}$ The Nemeroff opinion itself states that "the standard involved is akin to that of malicious prosecution." 81 Indeed, one court of appeals that prefers the use of malicious prosecution suits to deter frivolous claims has criticized fee-shifting motions because they "render a judgment against [the plaintiff] for damages under the guise of fixing costs." 82

If, as these courts suggest, a request for attorneys' fees under the bad faith exception is really a malicious prosecution suit in disguise, one would expect the respondent's right to due process and an evidentiary hearing to be the same in both contexts. In malicious prosecution actions, the existence of probable cause for the underlying suit is usually determined by the judge as a matter of law. ${ }^{83}$ Issues of fact relating to the question of motive, however, are aired in adversary proceedings and submitted to the trier of fact unless either side's evidence is simply incredible. The trier of fact may infer improper purpose from the lack of probable cause, ${ }^{84}$ but the

base the claim and reasonably believe that on those facts the claim presents a valid cause of action. Restatement (SECOND) of Torrs $\$ 675$ (1977). The underlying policy here strongly resembles that behind the lack-of-foundation requirement of the common law bad faith exception:

In many cases civil proceedings, to be effective, must be begun before all of the relevant facts can be ascertained to a reasonable degree of certainty. To put the initiator of civil proceedings to a greater risk of liability would put an undesirable burden upon those whose rights cannot be otherwise effectively enforced.

Id. comment $\mathrm{d}$ at 459 .

79 Cf. text accompanying note 27 supra (opposing party's claim must have been brought for improper purpose). Examples of improper purpose include the desires to deprive the defendant of the beneficial use of his property or to force a settlement that has no relation to the merits of the claim. Restatement (SEcond) of ToRTs $\$ 676$, comment $c$ at 462-63 (1977). Dean Prosser observes that findings of malice have been made in suits begun for any purpose other than adjudication of the claim in suit. W. Prosser, LAW OF TorTs $\$ 120$, at 855 (4th ed. 1971).

The three requirements listed in the text have been recognized and have remained constant for more than a century. See Stewart v. Sonneborn, 98 U.S. 197 (1878). In some states the English rule is followed, and a fourth requirement is imposed: that the defendant have suffered special damage. See Note, supra note 76 , at 1220 .

${ }^{80}$ See, e.g., Smoot v. Fox, 353 F.2d 830 (6th Cir. 1965); Lawrence v. Fuld, 32 F.R.D. 329, 332 (D. Md. 1963).

81 Nemeroff v. Abelson, 469 F. Supp. 630, 640 (S.D.N.Y.), appeal docketed, No. 73-7366 (2d Cir. May 25, 1979).

82 Smoot v. Fox, 353 F.2d 830, 832 (6th Cir. 1965).

83 See Note, supra note 76 , at 1235 n.116.

84 See W. Prossen, LAw of Torts $\$ 119$, at $849, \$ 120$, at 855 (4th ed. 1971). 
defendant will have had the opportunity to overcome any such inference by presenting evidence that shows that he did not file the suit with the requisite bad intent. ${ }^{85}$

An evidentiary hearing in court appears to be no less necessary when the court is asked to award attorneys' fees. ${ }^{86}$ There is no reason that a judge deciding a fee-shifting motion cannot likewise draw an initial inference of improper motive from the circumstances of the filing of a claim or from the probative value of the evidence that the opposing party had marshaled by the time the claim was disposed of summarily. ${ }^{87} \mathrm{~A}$ court should be wary of treating that inference as "all but irrebuttable," 88 however, and should at most merely shift to the opposing party the burden of producing some evidence of his subjective good faith. ${ }^{s 9}$

\section{The Lessons of Summary Judgment}

To say that a fee-shifting motion is akin to a suit for malicious prosecution is not to say that every such motion must be tried in open court. Summary proceedings, modeled on the well-tested practice on motions for summary judgment, ${ }^{90}$ may be appropriate in some cases. Once the threshold finding that the claim or defense was unfounded was made, the parties would be given time for discovery relating to the issue of plaintiff's good faith. As in summary judgment proceedings, each party would then submit to the court affidavits, depositions, and other written evidence probative of motive. ${ }^{91}$ If, upon an evidentiary hearing, no genuine issue of material fact was raised, ${ }^{92}$ a summary disposition could be made. If a dispute was clearly present, an adversary hearing would be held at which oral testimony would be taken, witnesses would be subject to cross-examination, and the judge would have the opportunity to

85 Id. 849.

86 Because the court's power to award fees under the bad faith exception is classified as equitable, the party opposing the award has no clear right to a jury trial. All that is contended here is that a judge's factfinding mission in the feeshifting and malicious prosecution contexts is one and the same and should be accomplished by means of an evidentiary hearing and, if necessary, oral testimony subject to cross-examination.

87 See text accompanying notes 55-56 supra.

88 Nemeroff v. Abelson, 469 F. Supp. 630, 635 (S.D.N.Y.), appeal docketed, No. 79-7366 (2d Cir. May 25, 1979).

89 See note 55 supra.

90 See FED. R. Crv. P. 56.

91 Compare this procedure with the treatment of motive in the cases discussed in the text accompanying notes 57-62 \& 68-71 supra.

92 FED. R. Crv. P. 56(c); see Poller v. Columbia Broadcast. Sys., Inc., 368 U.S. 464 (1961). 
observe the demeanor and evaluate the credibility of the witnesses. ${ }^{93}$ Such a proceeding might put the parties and the court to greater time and expense than does current practice, but as long as subjective bad faith remains a prerequisite of an award of attorneys' fees, judges will not always be able to base their decisions on written evidence alone.

Two caveats, in the form of well-established principles of summary judgment practice, must be noted in connection with the proposal. First, if a motion for summary judgment requires the judge to assess the relative credibility of the parties' witnesses or exhibits without the benefit of cross-examination, then the motion should usually be denied.94 Accordingly, summary disposition of fee-shifting motions frequently may be inappropriate, because a finding of motive often must be based on a judgment about the relative credibility of the parties. In practical terms, the propriety of summary proceedings may depend on the kind of evidence offered to the court. When the only evidence supplied is in the form of affidavits, summary disposition is probably unsuitable..$^{95}$ On the other hand, the evidentiary benefit of cross-examination is preserved when the court is provided with detailed depositions; ${ }^{96}$ if, on the basis of such depositions, the judge determines that the opposing party's argument is simply incredible, a summary award of fees to the movant may be made. ${ }^{97}$

Because the facts relevant to motive are often within the personal knowledge of the party opposing the award, the movant for fees may benefit from a deposition or trial-like proceeding. ${ }^{98}$ In

93 See genetally 6 Moore's FederaI Practice I56.15[4] (2d ed. 1979).

94 See Poller v. Columbia Broadcast. Sys., Inc., 368 U.S. 464, 473 (1961) ("It is only when the witnesses are present and subject to cross-examination that their credibility and the weight to be given their testimony can be appraised. Trial by affidavits is no substitute for trial by jury which so long has been the hallmark of 'even handed justice." "); see also 6 Moore's Federal Practice I 56.15[4], at 56-519 (2d ed. 1979).

95 See Poller v. Columbia Broadcast. Sys., Inc., 368 U.S. 464, 473 (1961); 6 Moore's Federal Practice I 56.15[4], at 56-514 (2d ed. 1979).

96 See Miles v. Dickson, 40 F.R.D. 386, aff'd in part, gev'd in part on other grounds, 387 F.2d 716 (5th Cir. 1967); Radio City Music Hall Corp. v. United States, 135 F.2d 715 (2d Cir. 1943); see also 6 Moore's Federal Practice I56.15[4], at 56-513 (2d ed. 1979).

97 Compare an oft-quoted test for determining when summary judgment may be granted: in Whitaker v. Coleman, 115 F.2d 305, 306 (5th Cir. 1940), the court said that a party could win on summary judgment if the opposing party's "tendered evidence is in its nature too incredible to be accepted by reasonable minds."

98 When the motive of procedural tactics during trial is at issue, access to proof is less likely to be a problem. See note 40 \& accompanying text. 
the summary judgment context, this "access to proof" problem has given rise to the general rule-our second caveat-that anything less than a trial-like proceeding "is particularly inappropriate where the inferences which the parties seek to have drawn deal with questions of motive, intent, and subjective feelings and reactions." 99 Considerations of judicial economy dictate that this principle not be carried to extremes. Summary disposition may still be appropriate against a movant who utterly fails to produce any affirmative evidence of the opposing party's bad faith in the face of the latter's assertions of nonmalicious error. ${ }^{100}$

In short, although summary judgment often will not be appropriate, courts should be sure that a fee-shifting "trial" is necessary before ordering one, for the prospect of such a lengthy proceeding may have the effect of deterring both potentially meritorious claims and potentially justifiable requests for fees.

\section{Nemeroff Reexamined}

The foregoing sections probe some of the procedural implications of making subjective bad faith a prerequisite for the equitable award of attorneys' fees. Against this background, the flaws in Judge Carter's treatment of the fee-shifting motion in Nemeroff $v$. Abelson ${ }^{101}$ are evident. The defendants in Nemeroff were awarded fees even though their allegations of improper motive had been

99 Cross v. United States, 336 F.2d 431, 433 (2d Cir. 1964) (quoting Empire Elec. Co. v. United States, 311 F.2d 175, 180 (2d Cir. 1962)); accord, Poller v. Columbia Broadcast. Sys., Inc., 368 U.S. 464, 473 (1962).

100 Summary judgment practice in libel actions by public figures is a useful analogue. For just as the exercise of first amendment rights might be chilled if harsh sanctions were imposed in such libel suits for mere negligence, so use of the courts might be deterred if negligence were the standard for award of fees. In fact, a showing of actual malice is central to both those libel actions and motions for fees. As Judge Carter himself noted, a groundless suit has the same potential for damage to a person's reputation as does a defamatory statement. Nemeroff v. Abelson, 469 F. Supp. 630, 640 (S.D.N.Y.), appeal docketed, No. $79-7366$ (2d Cir. May 25, 1979).

It is difficult, but not impossible, for the plaintiff in a public-figure libel suit to survive a motion for summary judgment. See T. EMrerson, D. HABER, \& N. Dorsen, Poimtical and CivIL Righrs in the UNTIEd States 518-19 (4th ed. 1976). A recent decision of the Supreme Court, in Herbert v. Lando, $99 \mathrm{~S}$. C. 1635 (1979), serves to underscore the importance of the opportunity to inquire directly into the state of mind of the opponent before a motion for summary judgment is entertained. In Lando, the Court held that even the first amendment did not shelter publishing defendants from court-ordered compulsory discovery into their state of mind at the time of publication of the statement in question. By analogy, in fee-shifting motions the interest in not inhibiting potentially meritorious lawsuits should not be held to preclude movants for fees from cross-examining their opponents, either in deposition proceedings or in full hearings.

101469 F. Supp. 630 (S.D.N.Y.), appeal docketed, No. 79-7366 (2d Cir. May $25,1979)$. 
disputed by the plaintiff-a genuine issue of material fact had been raised. Yet it is at best unclear from Judge Carter's opinion whether the parties treated the hearing that was held as an evidentiary one focusing on the plaintiff's state of mind. For instance, neither party devoted much attention to the question whether the complaint had been intentionally leaked to the press before it was filed. ${ }^{102}$ Judge Carter, however, attached great significance to this question, and so should have resolved it on the basis of examination and crossexamination of those involved. Instead, his conclusion that the plaintiff had leaked the complaint deliberately ${ }^{103}$ and maliciously ${ }^{104}$ was drawn solely from the affidavits of two interested parties-a defendant and his employee. ${ }^{105}$ The judge thus apparently discredited the plaintiff's sworn affidavits of good faith without the caution usually observed in deciding issues of credibility and questions of motive. Other factual disputes that should have been resolved through depositions or in open court concerned the con-

102 Defendant Abelson's memorandum of law refers to this fact only once, in its introductory statement of facts. Defendant's Memorandum in Support of Motion for Costs and Expenses Including Reasonable Attorneys' Fees at 12, Nemeroff v. Abelson, 469 F. Supp. 630 (S.D.N.Y.), appeal docketed, No. 79-7366 (2d Cir. May 25, 1979). The contents of plaintiff's memorandum were discussed over the telephone with Nemeroff's attorneys.

103 Nemeroff v. Abelson, 469 F. Supp. 630, 635 (S.D.N.Y.), appeal docketed, No. 79-7366 (2d Cir. May 25, 1979): "[T] allegations [was] done with conscious deliberation. The evident purpose was to secure maximum publicity harmful to the publishing defendants."

104 Id. 636: "The [decision] . . . to supply copies of the pleadings to the press even before the complaint was actually filed severely compromise[s] [plaintiff's] assertions of good faith."

${ }^{105}$ See Brief for Appellants at 28, Nemeroff v. Abelson, No. 79-7366 (2d Cir. May 25, 1979).

Judge Carter's one-sided discussion of this incident illustrates clearly the need in this case for an evidentiary hearing to test the truth of these affidavits. Drawing from them, the opinion states:

On the day the suit was filed ... a newspaper reporter telephoned Barron's to speak to Abelson. . . B Bleiberg [the editor] returned the call and was told that [the reporter] had a copy of the complaint and wanted to talk about it. Bleiberg then sent an office assistant to the courthouse to be told that no such complaint had been filed. Later, he obtained a copy and the clerk's notation indicates that the complaint was filed at $3: 38$ P.M.

Nemeroff v. Abelson, 469 F. Supp. 630, 635 (S.D.N.Y.), appeal docketed, No. $79-7366$ (2d Cir. May 25, 1979). Beyond this circumstantial evidence, Judge Carter did not recite-and the affidavits did not supply-any facts indicating that the plaintiff's attorneys had intentionally "leaked" the complaint before filing in order to obtain maximum publicity adverse to the publishing defendants. Nemeroff's attorneys, on the other hand, have advanced a plausible explanation for the incident: in the course of the preliminary investigation of the case, a reporter with the newspaper that obtained the complaint had been interviewed because he had written articles containing similar allegations about Abelson's activities. Brief for Appellants at 29, No. 79-7366 (2d Cir. May 25, 1979). 
tent and nature of various conversations ${ }^{106}$ and the reasons Nemeroff dropped the suit ${ }^{107}$-the latter being of undoubted significance for a finding on the bad faith issue.

\section{Proposals for Change}

\section{A. Procedures for Consideration of Motive-Related Evidence}

This Comment has established that courts award attorneys' fees in a variety of ways according to strikingly different interpretations of traditional standards. Nemeroff $\nu$. Abelson ${ }^{108}$ suggests a new readiness to impute bad faith to a litigant when it appears that he has no solid admissible evidence upon which to base his claim or defense. In some earlier cases, on the other hand, courts strained to find that the litigant had "reasonable suspicions" upon which to base his claim and from which the court could infer good faith. ${ }^{109}$ This variation in the application of the bad faith exception makes it extremely difficult to predict whether attorneys' fees will be awarded in a given case. The consequence is a deterrent effect. A person with a good faith complaint but little or no solid factual evidence to support it may be advised not to litigate the claim; a defendant who knows he has been taken to court in bad faith may choose to settle rather than risk being unable to recover his litigation expenses.

In order to eliminate both this unwarranted deterrent and the risk that a good faith claimant will be penalized and stigmatized on the basis of unsubstantiated judicial inferences, courts should adopt uniform procedures that are fair to the parties. These procedures should reflect both the close similarity between fee-shifting motions and malicious prosecution suits ${ }^{110}$ and also the desirability of avoiding expensive full-scale proceedings when one party's evidence is

100 See Brief for Appellants at 21, Nemeroff v. Abelson, No. 79-7366 (2d Cir. May 25, 1879).

107 The opinion states that the plaintiffs suit completely collapsed. Nemeroff v. Abelson, 469 F. Supp. 630, 632-33 (S.D.N.Y.), appeal docketed, No. 79-7366 (2d Cir. May 25, 1979). The plaintiff's attorneys, however, contend that the suit was dropped for reasons unrelated to the claim's merits: "[H]e decided the financial and personal burdens of continuing the litigation were too great." Brief for Appellants at 32, Nemeroff v. Abelson, No. 79-7366 (2d Cir. May 25, 1979). Among these burdens were attacks launched against Nemeroff by Abelson in his widely read and influential column. Id. 31-32.

108469 F. Supp. 630 (S.D.N.Y.), appeal docketed, No. 79-7366 (2d Cir. May 25, 1979).

109 See note 66 supra \& accompanying text.

110 See notes 76-89 supra \& accompanying text. 
either so insubstantial or incredible that summary disposition is appropriate. ${ }^{111}$

Fairness to the parties, however, is not the only consideration that must shape the procedures used in applying the bad faith exception. The interest in judicial efficiency must also be served. For example, the judicial policy of favoring voluntary dismissals of actions suggests that plaintiffs who take that step generally ought not risk punishment through an award of attorneys' fees to defendants. ${ }^{112}$ Rather than "straitjacketing" 113 a court by mandating a hearing in such circumstances, the law should impose upon the defendant seeking fees an extremely heavy burden of proof: unless he can establish a prima facie case of bad faith through written evidence, the motion for award of fees should be summarily dismissed.114 Although the analogy to summary judgment procedure cautions against depriving the movant of an opportunity to try the issue of intent, ${ }^{115}$ the expense and time of the proceedings, combined with the reluctance to "punish" voluntary dismissals, 116 tips the scales toward denial of movants' requests for such hearings. But if a prima facie case of bad faith is established, as perhaps in Nemeroff, fairness requires that the opposing party be afforded the same opportunity to prove his good faith as if the claim or defense had been dismissed at a later stage. ${ }^{117}$

When the motion for attorneys' fees is made at a later stagefor instance, after the opposing party has suffered defeat on summary judgment or directed verdict-the countervailing efficiency interest in encouraging voluntary dismissals is missing and the argu-

111 See text accompanying notes $97 \& 100$ \& following note 100 infra.

112 The general rule is that "[a]bsent a showing of exceptional circumstances, an award to defendant of costs and attorney's fees is improper where plaintiff obtains a voluntary dismissal with prejudice." 5 Moore's Federal Practice If 41.06 n.5, at 41-86 to -87 (2d ed. 1979) (citing, e.g., Mobile Power Enterprises, Inc. v. Power Vac, Inc., 496 F.2d 1311 (10th Cir. 1974); Smoot v. Fox, 353 F.2d 830 (6th Cir. (1965)). See Larchmont Eng'r, Inc. v. Toggenburg Ski Center, Inc., 444 F.2d 490, 491 (2d Cir. 1971): "[P]laintiff may well have decided in good faith to minimize litigation expense by foregoing its claims and by taking a voluntary dismissal. Such a move should not be discouraged by the threat of imposing attorney fees."

113 Larchmont Eng'r, Inc. v. Toggenburg Ski Center, 444 F.2d 490, 491 (2d Cir. 1971).

114 See, e.g., W.L. Gore \& Assoc., Inc. v. Oak Materials Group, Inc., 424 F. Supp. 700, 702-03 (D. Del. 1976).

115 See notes 98-100 supra \& accompanying text.

116 See notes 112 supra.

117 This is consistent with procedure in malicious prosecution suits. See note 85 supra \& accompanying text. 
ments for promoting procedural fairness become compelling. ${ }^{118}$ Evidence relating to motive must be heard if courts are to award sizable ${ }^{119}$ fees as punishment ${ }^{120}$ for bad faith litigation. The following scheme is proposed as a means of accommodating the frequently competing goals of fairness and economy in the disposition of motions under the bad faith exception. ${ }^{121}$

After a summary disposition of the plaintiff's claim, ${ }^{122}$ a rebuttable inference of plaintiff's bad faith may be derived from circumstances surrounding the claim, such as the absence of any disputed facts, colorable question of law, or admissible evidence. Any depositions, admissions, or other exhibits demonstrating the alleged improper purpose of the claim may be introduced along with a brief or memorandum supporting the fee-shifting motion. The movant having thus satisfied his burden of production, his opponent then has an opportunity to present rebuttal evidence in the form of a brief and supporting depositions or affidavits. Obviously, the opposing party should not simply assert his good faith, but should recount whatever sincere suspicions motivated the claim or defense, chronicle any efforts made to verify it, and describe the ultimately fruitless strategy of discovery or investigation by which he had hoped to document his suspicions. Unless rebuttal evidence is not forthcoming or is thoroughly incredible, the judge will then compare the parties' evidence to determine whether genuine issues of fact are raised. If they are, the party bearing the ultimate burden of persuasion-the movant-must choose whether or not he wishes to pursue the matter further through a trial-like hearing. Because the issue in controversy involves motive and subjective intent, the movant's request for such a hearing should be honored. If he decides not to go to that added expense, the matter is ended. If a hearing is requested and held, the interests of both parties are

118 For an argument that measures to ensure procedural fairness in such cases actually enhance judicial efficiency, see text accompanying notes 123-26 infra.

118 Judge Carter awarded $\$ 50,000$ in Nemeroff, and that case was dismissed at a relatively early stage. Nemeroff v. Abelson, 469 F. Supp. 630, 642 (S.D.N.Y.), appeal docketed, No. 79-7366 (2d Cir. May 25, 1979).

120 See text accompanying notes $41-42$ supra.

121 The author wishes to thank Robert Aronson, Visiting Associate Professor of Law at the University of Pennsylvania, for his valuable advice in the preparation of this proposal.

122 As was discussed in the text accompanying note 33 supra, such dispositions provide the basis for findings that the first two prerequisites for a fee award under the bad faith exception-movant as prevailing party and lack of foundation of opposing party's claim-have been met. This proposal is therefore addressed only to the third element-bad faith. 
served because the court will be deciding the issues not solely on the basis of paper evidence but also on the testimony of witnesses subject to cross-examination.

The objection that additional evidentiary hearings will consume already scarce judicial resources ignores not only the dictates of fairness, but also the possibility that such hearings may have the net effect of increasing judicial efficiency. When the trial judge disposes of a fee-shifting motion without benefit of an evidentiary hearing, a losing party's argument for de novo review of the facts by an appellate court ${ }^{123}$ will be stronger than if the trial judge had heard testimony and thus had been in a superior position to evaluate credibility. Lacking a justification for deference to the lower court's finding of facts, the appellate court may end up having to duplicate the trial court's examination of exhibits and affidavits. ${ }^{124}$ And, of course, the same argument applies when the trial court has not even considered any written evidence related directly to motive. ${ }^{125}$ In this latter case, the appellate court does not duplicate the trial court's efforts; rather it takes time away from the performance of its usual appellate function to make initial findings of fact. ${ }^{126}$

The analysis above shows that explicit consideration of motiverelated evidence is necessary if fees are to be awarded fairly under the bad faith exception. For reasons of judicial economy, however, courts may be reluctant to expend the additional resources necessary to make the finding of motive properly. Judge Carter showed no inclination to prolong the Nemeroff litigation in order to consider evidence directly related to motive, even though the size of

123 Nemeroff's attorneys have made such an argument in their brief to the Second Circuit Court of Appeals. Brief for Appellants at 35, Nemeroff v. Abelson, No. 79-7366 (2d Cir. May 25, 1979).

124 See, e.g., Browning Debenture Holders' Comm. v. DASA Corp., 560 F.2d 1078 (2d Cir. 1977); Aid Auto Stores v. Cannon, 525 F.2d 468 (2d Cir. 1975).

125 But compare Larchmont Eng'r, Inc. v. Toggenburg Ski Center, Inc., 444 F.2d 490, 491 (2d Cir. 1971), in which the court upheld a trial judge's denial of a defendant's requests for attorneys' fees and for an evidentiary hearing on the question of the plaintiff's bad faith. The appeals court declined to disturb the judge's decision and announced that "[t]he question is peculiarly one within the discretion of the Nisi Prius judge who in this case was more familiar than we are with the claims and with the likelihood of defendants' establishing bad faith." Id. 491. Larchmont can, however, be read more narrowly as applying only to cases in which the plaintiff voluntarily dismisses his claim. See text accompanying notes 69-71 supra.

126 Deference to a trial judge's findings may be more appropriate when attorneys' fees are awarded because of a party's procedural bad faith (e.g., haphazard discovery, dilatory tactics, or service of dragnet subpoenas; see note $\mathbf{4 0}$ supra). In these cases, the lower court will have been in a superior position to evaluate the tactics of the opposing counsel. 
the attorneys' fees at issue was quite considerable. ${ }^{127}$ In light of the widespread concern over congestion in the courts ${ }^{128}$ and the related problem of unfounded litigation, it is important that courts resist the urge to award fees quickly without due regard for procedural fairness. Indeed, the chance that huge sums of money will be at stake makes fairness in motions for attorneys' fees that much more essential.

\section{B. Do the Critics of the American Rule Have a Point?}

Perhaps the foregoing exposition of proper practice under the bad faith exception adds weight to the argument that the American Rule for awarding attorneys' fees is inefficient. ${ }^{129}$ Various critics of the rule have advanced proposals for making the award of fees contingent on more objective factors. ${ }^{130}$ Because it is the criterion of motive which necessitates the additional litigation of fee-shifting motions, one way to increase efficiency is simply to eliminate motive as an issue. Fees could be shifted whenever the court was convinced the claim was unfounded, ${ }^{131}$ regardless of whether it was brought for an improper purpose. Such a wholesale modification of the American Rule, the Supreme Court has said, ${ }^{132}$ can be adopted only by Congress. In fact, Congress has already changed the rule in specific categories of litigation, such as suits under the 1964 Civil Rights Act. ${ }^{133}$ With extension of the rule to all classes of litigation would have to come a change in philosophy. No longer would punishment be the paramount goal; ${ }^{134}$ rather, the emphasis

127 Judge Carter awarded $\$ 50,000$ to the publishing defendants. They actually incurred over $\$ 100,000$ in fees and expenses, but the judge concluded that "an award of part of these expenditures seems to me sufficient." Nemeroff v. Abelson, 469 F. Supp. 630, 642 (S.D.N.Y.), appeal docketed, No. 79-7366 (2d Cir. May 25, 1979).

128 See note 1 supra \& accompanying text.

129 See note 5 supra.

180 See, e.g., Ehrzenweig, Shall Gounsel Fees Be Allowed?, 26 CAL. ST. B.J. 107, 107-09 (1951) (universal indemnification); Mause, Winner Takes All: A Re-examination of the Indemnity System, 55 Iowa L. Rev. 26, 48 (1969) (fees awarded according to reasonable probability of claim's success); Comment, Court Awarded Attorney's Fees and Equal Access to the Courts, supra note 3, at 652-55 (legislative enactment of method to shift fees in "unreasonable" suits); Note, supra note 76, at 1232-37 (lack of probable cause).

131 Cases that involve dismissals for failure to state a claim under current law may merit separate treatment. See note 137 infra \& accompanying text. (1975).

132 Alyeska Pipeline Serv. Co. v. Wilderness Soc'y, 421 U.S. 240, 262, 271

13342 U.S.C. $\$ 2000 \mathrm{e}-5(\mathrm{k})(1976)$. See Christianburg Garment Co. v. EEOC, 434 U.S. 412 (1978).

134 See Hall v. Cole, 412 U.S. 1, 5 (1972); text accompanying note 42 supra. 
would be on compensating parties who have been forced to resist unsubstantiated or otherwise improper claims or defenses.

In concrete terms, the rule would work in the following manner. Reasonable attorneys' fees incurred in connection with any claim or defense that was disposed of summarily for lack of factual support would be paid by the losing party. Compensation would not be ordered simply because the suit, when filed, was not based on any admissible evidence; rather, fees would be assessed on the basis of the outcome of summary disposition because, before a motion for summary disposition is considered, a litigant is afforded a reasonable time to document his claim through discovery. ${ }^{135}$ Thus, compensation for attorneys' fees would be ordered only when a party had instituted a suit with no solid evidentiary support, had not been able to document his claim through the discovery process, and had not chosen to dismiss it voluntarily ${ }^{136}$ before the court ruled on a motion for summary judgment or directed verdict.

Fees would not be shifted when, on the stipulated facts, the loser's claim was not valid under current law. This distinction between lack of factual and legal basis of the claim is necessary to ensure the continued development of the law through consideration of claims based on suggested reforms. ${ }^{137}$

This objective compensatory scheme is not necessarily better than the procedure suggested above for hearing motive-related evidence under the bad faith exception. Each reflects a different philosophy of fee shifting. Both would help deter groundless litigation. Either is superior to the current practice of punitive fee shifting improperly administered without presentation of evidence relating to motive.

135 See 6 Moore's Federad Practice $\{56.02[8]$, at 56-38, I56.15[6], at 56-608 (2d ed. 1979); note 100 supra.

136 See notes 112-16 supra \& accompanying text.

137 The ABA CODE of Professional Responsmbicriy supports the view that such claims should not be discouraged. Id. Disciplinary Rule 7-102(A)(3) provides that "a lawyer shall not knowingly advance a claim or defense that is unwarranted under existing law, except that he may advance such claim or defense if it can be supported by good faith argument for an extension, modification, or reversal of existing law." 